\title{
Public Standards and Private Monitoring: New Zealand's New Banking Supervision Regime
}

\author{
Arthur Grimes
}

\begin{abstract}
7 He Reserve Bank of New Zealand (RBNZ), which is well-known for its independence and anti-inflation stance under the Reserve Bank of New Zealand Act 1989, has embarked on another policy innovation. In January 1996 , it implemented a new approach to banking supervision. Defying international trends, the RBNZ reforms envisage returning 'supervision' largely to the private sector, although the RBNZ retains a role in specifying minimum standards for banks to meet.

This article outlines and analyses these proposals, in the context both of the broader reform process in New Zealand since 1984 and of international and academic developments. It also considers whether certain aspects of the proposals could be altered so as to better meet the Reserve Bank's objectives.
\end{abstract}

\section{Government as Risk Bearer}

Before 1984, New Zealand economic policy was frequently characterised by government assuming the role of a major bearer of risk, whether direct commercial risk arising from government ownership of enterprises, or indirect risk associated with explicit or implicit indications of government support for firms or industries in financial distress. In the financial sector, for instance, government directly owned, inter alia, the largest bank (the Bank of New Zealand) and a large insurance company (State Insurance). In other sectors, such as agriculture, government's assumption of risk took the form of subsidising producers when returns were poor.

Government's willingness to bear risk was complemented by substantial regulation, in part designed to reduce the risk of institutional failure and of consequent government financial support. Regulation frequently took the form of limiting entry (and competition) in certain sectors (including the banking sector) and/or of limiting the activities that institutions in certain sectors could undertake. In this respect, banks were heavily regulated in terms of pricing (interest-rate controls) and asset choice (credit and directed-lending controls).

Arthur Grimes is Chief Executive of Southpac Investment Management Limited and a former Chief Manager of the Financial Markets and Economics Departments of the Reserve Bank of New Zealand. 
The Labour government that assumed office in 1984 sought to reduce government's role of 'risk-bearer of last resort'. It also aimed to increase consumer choice by eliminating, or at least reducing, regulations (including restrictions on entry) pertaining to certain sectors. Emphasis was placed on market-oriented mechanisms that generated incentives for individuals to act commercially, especially with regard to monitoring and dealing with risk. The RBNZ's new banking supervision proposals embody this policy approach.

\section{International Banking Supervision Developments}

Banking supervision issues have assumed a high profile throughout the world over the past decade. Partly, this has been a result of a series of spectacular failures of financial institutions, including BCCI, Barings Bank, the Savings and Loans (S\&Ls) and many small banks in the United States, major banks in Scandinavia, regional banks in Canada and, most recently, the Japanese banking system. Closer to home, State banks and other small financial institutions have failed in Australia, and banking problems were experienced in New Zealand following the 1987 sharemarket crash.

At the same time, there has been a trend towards greater international coordination amongst banking supervisors, mainly as a result of European initiatives under the auspices of the Bank for International Settlements (BIS) in Basle. In the mid1980s, European and United States supervisors were concerned that other jurisdictions (notably Japan) were imposing less stringent rules on banks than their own, so increasing the incentive to relocate banking functions to less regulated markets. They themselves had little incentive to reduce regulation in their own markets, often regarding it as necessary to underpin the stability of their own financial systems.

More important, however, is the principal-agent problem embodied in banking supervision. The supervisor is the agent of government (and ultimately, the public) in regulating and supervising the banking system. Whatever the optimal degree of regulation is, supervisors will generally have an incentive to over-regulate ex ante. ${ }^{\mathbf{I}}$ This behaviour derives from the simple nature of the pay-off structure to supervisors. If no bank failure occurs (or is seen to occur) within their jurisdiction, they have a certain pay-off. But if failure does occur, even where the regulator has followed the ex ante optimal supervisory regime, the pay-off for regulators will be substantially reduced (jobs may be lost, and reputations will suffer). In contrast, there is almost no negative pay-off to a regulator who over-regulates, unless banking services migrate to other jurisdictions.

The aim of the Basle approach was to standardise supervisory approaches and standards across major jurisdictions, largely in order to prevent the migration of banking functions. The resulting Basle standards were not legally binding on other

\footnotetext{
${ }^{1}$ In practice, regulators may be weak in enforcing regulations $e x$ post because they wish to keep banking problems hidden both from those who monitor their performance and from the public, in the hope that a bank can restructure or trade its way back to an adequate capital position. This is known as 'regulatory forbearance'.
} 
countries, but their adoption by the major countries made it difficult for other jurisdictions to adopt less stringent regulations while maintaining their reputations as banking centres. The Basle approach can therefore be characterised as an international banking supervisory cartel, with barriers erected to reduce the likelihood of the cartel breaking down through 'regulatory undercutting'.

The first key development under the new Basle approach was the 1988 proposal for uniform minimum bank capital standards specified by the Committee on Banking Regulations and Supervisory Practices (also known as the Cooke Committee). This proposed minimum levels of tier 1 or 'core' capital (essentially, shareholders' equity and retained profits) and tier 2 or 'supplementary' capital (like subordinated debt and some forms of reserves) to be held as a proportion of riskweighted assets. Assets were weighted on a scale of zero to 100 , supposedly reflecting relative credit risks. Since then, position-risk parameters have been formulated, reflecting interest rate and exchange rate exposures, though they are not yet finalised.

All developed countries have adopted the Cooke Committee's capital standards, if not more stringent criteria. Many have also intensified their supervisory operations, often in response to bank failures. For instance, in 1992 the Reserve Bank of Australia began on-site inspections of banks' management systems for assessing asset quality, and in 1995 released a Prudential Statement guiding banks' identification of impaired assets (Reserve Bank of Australia, 1995). In the United States, the Federal Deposit Insurance Corporation Improvement Act 1991, designed to minimise regulatory forbearance, prescribed a series of steps to be taken as a bank's capital falls into successive tranches below the required capital ratio.

\section{Academic Developments}

The analysis of banking supervision is one of the less satisfactory fields of economic theory. Models tend to be highly unrealistic, to lack the ability to explain key features of banks, or to attempt to explain current features of regulatory systems without adequately questioning the validity of their assumptions (or admissible set of solutions). For instance, the frequently cited article by Diamond and Dybvig (1983), which seeks to explain how bank runs can occur, apparently justifies deposit insurance, with associated monitoring of banks by the insurer. Yet many other responses, such as changing the nature of the deposit contract or adopting bank equity, would also solve the problem.

More recently, Dewatripont and Tirole (1994) have argued that the key function of banking regulation and public supervision is to correct a market failure in monitoring bank performance. Small depositors in banks do not have the incentive individually to monitor bank behaviour because their exposure is small compared with the high cost of detailed monitoring. According to Dewatripont and Tirole's 'representation hypothesis', public monitoring efficiently takes the place of inadequate private-sector monitoring of banks by debt holders. The banks differ from non-financial firms, which generally have a major debt holder (normally a bank) with an adequate incentive to monitor closely a firm's actions. Dwatripont and Ti- 
role contend that this public-sector monitoring role, which effectively amounts to depositor protection, is more important than issues such as systemic stability (contagious bank runs, for example), which can be overcome through other means, such as acting as a lender of last resort.

Yet this analysis, like many other academic contributions on the subject, tends to take for granted existing supervisory approaches, such as on-site inspections and the existence of deposit insurance, without analysing fully their shortcomings. It also ignores more radical options that may overcome the problems. Academic analyses of banking supervision thus tend to be less incisive than analyses of other fields of regulation, so giving less guidance to policy-makers secking to explore alternative regimes.

\section{New Zealand Banking Developments}

In the late 1980 s, New Zealand, in common with many other countries, endured a number of banking problems. The Development Finance Corporation, a moderately sized and partly government-owned financial institution, became insolvent; the Bank of New Zealand, the largest (and then government-owned) bank, had to be rescued twice by its parent; and another mid-sized institution, NZI Bank, had to be rescued (and ultimately closed) by its new parent, General Accident. A number of fringe non-bank finance companies also became insolvent and small depositors lost money as a result. In one instance, failure of a fringe finance company sparked a run on a large building society. Statements of comfort to depositors by the Reserve Bank and the building society's own bank stemmed the run.

Ironically, these failures occurred after the establishment of a fledgling banking supervision function by the Reserve Bank, under a 1986 amendment to the Reserve Bank Act. Before 1986, the Bank had had no explicit supervision function, although New Zealand's financial system had been heavily regulated for monetary policy purposes. The 1986 amendment opened the banking system to new entrants. It also enabled the Reserve Bank to prescribe capital ratios for new banks, though not for existing banks. Only with the Reserve Bank of New Zealand Act 1989 (which also introduced the new monetary policy regime) was a more typical supervision system introduced. This gave the Reserve Bank powers to impose capital ratios and large exposure limits on all banks. It also introduced a system whereby registered banks supplied the Reserve Bank with confidential returns on such matters as property exposures, which were analysed within the central bank.

The direction of the 1989 supervision system was towards more prudential regulation of banks and more intensive central-bank monitoring of their activity. The latter feature, however, raised a number of issues. Did the Reserve Bank believe it could interpret such material better than the banks themselves? On what basis should the results of Reserve Bank analysis of private bank information be communicated to the banks concerned? And should they be communicated to other parties, such as depositors? Above all, if the Reserve Bank had had private knowledge that a bank might fail, would its failure leave the Reserve Bank legally, or at least morally, liable to bail out depositors? This issue was especially pressing as 
New Zealand had never adopted a deposit-insurance scheme. Instead, authorities had publicly stated that no such insurance existed and that depositors were expected to monitor banks to check their soundness. This approach had been adopted because deposit insurance could create moral hazard, as it had in the United States.

In place of an explicit depositor protection focus for banking supervision, the New Zealand supervision system had the objectives, under the 1989 Act, of 'promoting the maintenance of a sound and efficient financial system' and 'avoiding significant damage to the financial system that could result from the failure of a registered bank'. This objective differs from the 'representation hypothesis' of Dewatripont and Tirole, whose insights, like those of other authors who assume a depositor protection objective, may therefore not apply to New Zealand. The same could be true of many other aspects of banking supervision that are prevalent elsewhere. For instance, it was not clear that Reserve Bank monitoring of private banking information contributed to the stated objective. If anything, it could be counterproductive if it contributed to an increase in moral hazard by giving the impression that implicit depositor protection existed as a consequence of central bank's receipt of private information not available to depositors. Such a belief could reduce monitoring by depositors and other stakeholders in banks and so increase the risk of failure of individual banks, with possible systemic consequences.

\section{The Review of the Conduct of Banking Supervision}

This was the background to a review of the conduct of banking supervision, which was initiated and conducted wholly within the Reserve Bank, and within the confines of the objectives for banking supervision set out above. At an interim stage of the review, the RBNZ (1993:48) stated its key concerns and its preferred approach in the following terms:

The common reaction to . . financial sector stresses has been intensified official regulation and supervision ... However, that reaction of more intensive intervention carries with it the seeds of future difficulties. At one level, there are reasonable doubts about whether even intensive supervision can be effective in recognising early, and dealing with, incipient bank failure. But there are more pervasive effects of intensified regulation and supervision which in the long term can run counter to the interests of the public at large.

As regulators and supervisors become more heavily involved in the affairs of banks, the normal incentives and market disciplines that shareholdcrs in banks should face are blunted. Bankers, their customers and creditors come to accept that the government, as regulator and supervisor, is making the key judgments about what is prudent behaviour and what is not. Consequently, the government can find itself effectively taking responsibility for ensuring that nothing goes wrong or, if it does, for picking up the tab. 
This approach, with its focus on the efficiency and incentive effects of regulation, came on top of analyses of the underlying characteristics of banking that might promote regulation in the first place (see for example White, 1992). The results of the review were released in 1994 (RBNZ, 1994). The new approach to supervision reflects the Reserve Bank's belief

that banking supervision is not necessarily an effective or efficient means of reducing banking system risks. Much of the information available to banking supervisors tends to be too dated by the time it reaches the supervisor to enable the supervisor to adopt measures to avoid a bank failure. Moreover, it is doubtful that supervisors are any better placed than bank management to recognise early signs of financial distress. (RBNZ, 1995:74).

\section{The Proposed System}

The key features retained or implemented in the new banking supervision framework are set out below.

Capital. The BIS Capital Accord is retained with unaltered risk weights. A minimum capital of $\mathrm{NZ} \$ 15 \mathrm{~m}$ is required to set up as a bank.

Disclosure. Banks must issue quarterly public disclosure statements. A full disclosure statement includes: an income statement and balance sheet, information on asset quality and provisioning, large exposures (the number of exposures between 10 per cent and 20 per cent of equity, between 20 per cent and 30 per cent of equity, and so on), exposures to related parties (such as the parent company), sectoral exposures, capital adequacy (including off-balance sheet exposures), market (position) risks, and board composition. A full statement must be available on request; in addition, a one- or two-page summary statement must be displayed in all branches.

External audit. Bank disclosure statements must be audited twice yearly by external auditors.

Credit rating. Banks with a credit rating for long-term senior unsecured debt must disclose this rating prominently; banks with no such rating must disclose this fact.

Directors' role. Directors must certify that the disclosure statements are not false or misleading and must attest to the adequacy of the bank's risk-management systems and internal controls.

Related parties. A limit is placed on maximum exposures to related parties as a proportion of tier 1 equity. 
Capital breach. A structured approach to breaches of capital adequacy is adopted, including:

- a ban on distributions to bank shareholders until minimum capital requirements have been dealt with;

- no increase in exposures to related parties until capital is restored;

- no increase in gross credit exposures once tier 1 capital falls below 3 per cent of risk-weighted assets.

Previous aspects of banking supervision that have been withdrawn or modified include:

Large exposures. The previous limit on individual large exposures as a proportion of capital has been removed (to be replaced by the disclosure of large exposures).

Foreign exchange. The previous limits on open foreign-exchange positions are removed (to be replaced by disclosure of position risks).

Internal controls. Previous Reserve Bank guidelines on internal controls are abolished (to be replaced by directors' attestations).

Private returns. The Reserve Bank will no longer obtain returns of confidential information from banks. Its information will be gathered from public sources.

The new system reflects the broad approach to (de)regulation within New Zealand since 1984. Responsibility for assuming and monitoring risk is returned to the private sector. Further, the framework has been accompanied by explicit government and Reserve Bank statements that government does not insure deposits in New Zealand banks. Thus, the framework attempts to minimise risk borne by government arising from banking problems and to ensure that there are adequate incentives for private-sector agents to manage and monitor risk.

Apart from the requirement to make detailed disclosure statements, the key surviving regulatory element is the capital adequacy controls and accompanying controls on related-party exposures. Even here, the Reserve Bank states that it considers that disclosure alone should ensure that banks hold adequate capital. It defends the retention of the minimum capital ratio principally by arguing that sticking with the BIS Capital Accord offers benefits in terms of maintaining international credibility of the supervision system (demonstrating the importance of the Basle cartel). It also argues that banks incur little, if any, cost as a consequence of this regulation since most banks would voluntarily hold at least the minimum specified capital.

\section{Analysis of the Reforms}

The difficulty that small depositors have in monitoring banks - which leads to Dewatripont and Tirole's 'representation hypothesis' - raises some issues about 
the efficacy of the RBNZ's proposals. The free-rider problem associated with small depositors means that no depositor has the incentive or the ability to monitor banks, even though detailed information is supplied in bank disclosure statements. With no public-sector monitoring, and with only voluntary credit ratings, bank managements may have insufficient incentives to operate banks prudently, especially where they may have private incentives to increase market share or short-term profitability by taking excessive risks that are not in the long-term interests of their principals.

However, the special nature of the New Zealand banking system, in which 90 per cent of deposits are held in banks with a dominant foreign bank shareholder such as Lloyds, Bank of Scotland, NAB, Westpac, ANZ, CBA, means that almost all banks have a parent with a reputation to uphold; and the Reserve Bank will continue to have regular discussions with parent banks' supervisory authorities. In practice, a parent bank would be most unlikely to let a subsidiary in New Zealand fail unless the parent itself were in trouble. The latter possibility explains the retention of regulations concerning related-party lending. Further, parent banks often stipulate key policies (such as risk-management policies) and place senior personnel in their New Zealand operations, or monitor the New Zealand operation with their own inspection personnel, so adding a level of monitoring that does not exist in stand-alone banks.

If we set aside this special aspect, it is evident that the nature of directors' roles and of the incentives created by the disclosure statements goes a long way to resolving the problems raised in the representation hypothesis. A director may incur fines or imprisonment if found guilty of signing a disclosure statement that is false or misleading. In addition, directors face unlimited liability if creditors lose money as a result of relying on a false or misleading disclosure statement. A director's incentives thus become more closely aligned to those of depositors, since if he or she acts counter to the depositors' interests and does not report this fact, then his or her wealth and reputation could disappear as a consequence. Directors are further encouraged to act prudently by the twice-yearly external audits and the need to report credit ratings.

However, principal-agent problems caused by asymmetric information between management and directors within a bank may mean that management could obtain directors' signatures to statements that are false, thereby causing a breakdown of this key safety feature of the RBNZ framework. In most systems, the presence of a state supervisor theoretically acts as a deterrent to management operating in this manner; but in practice this is doubtful, for the reasons outlined by the RBNZ. If neither directors nor state sector supervisors are fully effective in disciplining the actions and disclosures of bank management, and if small depositors do not monitor for free-rider reasons, are there additional safeguards against potential management abuse of information?

One candidate is the presence of large depositors or investors. Most large depositors (such as corporations) place money on deposit with banks for only short periods, and may therefore fail to monitor closely a bank's soundness. However, a 
large subordinated long-term debt holder (that is, one who is paid out only after all normal depositors have been repaid in the event of insolvency) has an incentive to monitor the bank's actions closely and so prevent excessive risk-taking by bank management. Because the return is fixed, the subordinated debt holder (unlike equity holders) normally has no incentive to promote excessive risk-taking within the bank. An exception to this rule could arise if the bank were near (or beyond) insolvency, in which case the subordinated debt holder may share the equity holder's incentive to 'gamble for resurrection' (as occurred with many of the S\&Ls in the United States). However, this would not be an option with the Reserve Bank's structured overlay of intervention once capital adequacy limits are breached.

This suggests that the RBNZ may wish to look further at the role of subordinated debt in its framework. At present, subordinated debt is counted as tier 2 capital. But the RBNZ may wish to encourage banks more explicitly to issue subordinated debt in large enough units to ensure that subordinated debt holders have an incentive to monitor actively the banks' position. This could be especially useful in cases where the bank has no parent bank with an established reputation to uphold. In these cases, a mandatory large subordinated debt holder may partially replicate the benefits of having a well-established parent bank. Such a move would retain the shift to private monitoring that the new structure has introduced. But it would add another external incentive to monitor bank actions closely, so further underscoring the stability of the system. This is particularly relevant for banks that have no foreign well-established parent bank.

Such an additional external monitor would complement the internal monitoring role of directors. This latter role has been greatly strengthened in the new regime. In contrast to normal international practice, the New Zealand framework has raised the duties of bank directors to a high level in ensuring the veracity of disclosures and the soundness of a bank. The provisions relating to the roles of directors, and penalties for breaches of these roles, may well be the features of the New Zealand reforms that are of most interest to other regulatory authorities, whether or not they intend to embark on a more prescriptive regulatory regime. 


\section{References}

Dewatripont, M. \& J. Tirole (1994), The Prudential Regulation of Banks, MIT Press, Cambridge, Mass.

Diamond, D. \& P. Dybvig (1983), 'Bank Runs, Deposit Insurance and Liquidity', Journal of Political Economy 91: 401-19.

Reserve Bank of Australia (1995), Report and Financial Statements, Sydney.

Reserve Bank of New Zealand (RBNZ) (1993), Post-Election Briefing Paper for the Incoming Minister of Finance, Wellington.

- (1994), Review of Banking Supervision: Reserve Bank's Policy Conclusions, Wellington.

— (1995), 'Review of Banking Supervision: Reserve Bank's Policy Conclusions', Reserve Bank Bulletin 58(2): 73-8.

White, B. (1992), 'Why are Banks Supervised?', pp.173-82 in Reserve Bank of New Zealand, Monetary Policy and the New Zealand Financial System (3rd edition), Wellington. 